\title{
Prognostic significance of genotyping Helicobacter pylori infection in patients in younger age groups with gastric cancer
}

\author{
S K Tiwari, ${ }^{1}$ G Manoj,, ${ }^{1}$ G Vasanth Kumar, ${ }^{1}$ G Sivaram, ${ }^{1}$ S I Hassan, ${ }^{2}$ B Prabhakar, ${ }^{2}$ \\ U Devi, ${ }^{2}$ S Jalaluddin, ${ }^{2} \mathrm{~K} \mathrm{Kumar},{ }^{2}$ S Ahmed, ${ }^{1}$ Z Abid, ${ }^{1,3}$ M A Habeeb, ${ }^{1}$ A A Khan, ${ }^{1}$ \\ C M Habibullah'
}

\section{See Editorial, p 167 \\ ${ }^{1}$ Center for Liver Research and Diagnostics, Deccan College of Medical Sciences, Kanchanbagh, Hyderabad, Andhra Pradesh, India; \\ ${ }^{2}$ Department of Gastroenterology, Osmania General Hospital, Afzalgunj, Hyderabad, Andhra Pradesh, India; ${ }^{3}$ Department of Pathology, Deccan College of Medical Sciences, Kanchanbagh, Hyderabad, Andhra Pradesh, India}

Correspondence to: Dr A A Khan, Center for Liver Research and Diagnostics, Deccan College of Medica Sciences, Kanchanbagh, Hyderabad 500 058, Andhra Pradesh, India; aleem_a_khan@rediffmail.com

SKT and GM contributed equally to this work.

Received 6 October 2007 Accepted 25 January 2008

\begin{abstract}
Background: Malignant tumours of the stomach are common, but the incidence of stomach cancer varies from country to country, probably a result of genetic, epigenetic and environmental factors. Stomach cancer often occurs in older people whose stomachs produce only small quantities of acid. Although infection with Helicobacter pylori has been proven beyond doubt in the aetiopathogenesis of various gastric disorders, not much is known about the genotypes of $H$ pylori infection in early-onset gastric cancer.
\end{abstract}

Aim: To ascertain the genotypes of $\mathrm{H}$ pylori in gastric cancer.

Methods: Ninety-two patients were separated into three groups on the basis of their endoscopic findings: group 1, gastric cancer; group 2, gastric ulcer; group 3, non-ulcer dyspepsia. Gastric biopsy specimens were obtained for culture and DNA isolation; additional specimens were taken from subjects with gastric cancer for histopathological analysis. Amplification was performed using specific oligonucleotide primers to obtain genotypic data. Four samples from each group were randomly selected for sequence analysis.

Results: Genotypic analysis showed cagT+ve/hrgA+ve/ cagA+ve/cagE+ve/vacAs1+ve to be highly prevalent in $79 \%$ of cases of $\mathrm{H}$ pylori infection. This genotype was found in 88\% of subjects in group 1 and 78\% in group 2 . Intestinal-type adenocarcinoma was found in 35 subjects (83\%), 32 (9\%) of which harboured this genotype.

Sequence analysis showed no significant strain-specific variations.

Conclusions: Certain genotypes of $H$ pylori have higher predictive value for the development of intestinal-type carcinoma at an early age. Genotyping of $\mathrm{H}$ pylori may well be a useful tool for screening people at increased risk of developing malignancy.

Gastric cancer is the second leading cause of cancer-related deaths worldwide. From the data provided by the International Agency for Research on Cancer, ${ }^{1}$ malignancy of the stomach is the most common cancer in Asia, nearly two-thirds of which occurs in developing countries. ${ }^{2}$ Despite a dramatic fall in the incidence and mortality of distal gastric cancers in the Western world, the incidence of proximal tumours is increasing, especially in the male population. In contrast, data from the Asian sub-continent reveal an increase in distal tumours on a par with proximal tumours. The marked geographic variation, differences in lifestyle, time trends and migratory effects associated with the incidence of gastric cancer suggest that environmental and lifestyle factors are major contributors to the aetiology of this disease. ${ }^{3}$

Our understanding of gastric cancer underwent a discernible shift with the discovery of Helicobacter pylori. Infection with $H$ pylori probably still plays a leading role in the development of gastric cancer in young patients. ${ }^{4}$ In a country such as India, where $>75 \%$ of the population are infected, it has been proved beyond doubt that $H$ pylori infection is high, especially in areas of low socioeconomic status and bad hygiene conditions. ${ }^{5}$ The vast majority of $H$ pylori-infected people remain asymptomatic throughout their lives with no major clinical sequelae, and only a small proportion present with some form of gastric disorder, such as gastric carcinoma and mucosa-associated lymphoid tissue (MALT) lymphoma. Of those infected, fewer than $10 \%$ present with the disease before 45 years of age, and these younger patients are thought to develop carcinomas with a different molecular genetic profile from that of sporadic carcinomas occurring at a later age. ${ }^{6}$ In support of this notion, a study by Konturek et al showed that the risk of gastric cancer in patients with $H$ pylori markedly increased with infection with bacteria that were cytotoxin-associated gene A (cagA)positive in the age group 40-49 years. Further, a similar study from the Indian sub-continent reported a higher risk of developing gastric cancer in younger patients ( $<45$ years) infected with $H$ pylori. ${ }^{8}$ Although some studies have rejected a direct link between $H$ pylori infection and gastric cancer, $^{89}$ several prospective studies have supported a positive association between these two entities. ${ }^{10} 11$ Perhaps the most convincing evidence for the association between $H$ pylori infection and gastric carcinoma was provided by a Japanese study, ${ }^{12}$ which showed development of gastric cancer in $2.9 \%$ of $H$ pylori-infected people, whereas no uninfected subjects developed it. In addition, a number of environmental factors have been shown to be associated with gastric cancer, including highsalt diets, $\mathrm{N}$-nitrosamines and low intake of dietary antioxidants typically found in fresh fruit and vegetables. ${ }^{13} 14$

Despite the vast array of data on gastric cancer, the exact mechanisms leading to this common cancer are far from understood. Several cofactors are believed to contribute to the overtness of the disease, which can be broadly categorised into: (a) 
Table 1 Genotypic distribution of Helicobacter pylori in subjects with different clinical presentations

\begin{tabular}{|c|c|c|c|c|}
\hline Genotype & $\begin{array}{l}\text { Gastric } \\
\text { carcinoma } \\
(\mathrm{n}=42)\end{array}$ & $\begin{array}{l}\text { Gastric ulcer } \\
(\mathrm{n}=18)\end{array}$ & $\begin{array}{l}\text { NUD } \\
(n=12)\end{array}$ & $\begin{array}{l}\text { Total } \\
(\mathrm{n}=72)\end{array}$ \\
\hline $\operatorname{cag} \mathrm{T}+\mathrm{ve} / \mathrm{cag} \mathrm{A}+\mathrm{ve} / \mathrm{cag} \mathrm{E}+\mathrm{ve} / \mathrm{hrg} \mathrm{A}+\mathrm{ve} / \mathrm{vac} \mathrm{As} 1+\mathrm{ve}$ & $37(88 \%)^{*} \dagger$ & $14(78 \%) \ddagger$ & $6(50 \%)$ & $57(79 \%)$ \\
\hline cagT+ve/cagA+ve/cagE+ve/hrgA+ve/vacAs2+ve & $2(5 \%)$ & $2(11 \%)$ & $4(33 \%)$ & $8(11 \%)$ \\
\hline cagT-ve/cagA-ve/cagE-ve/hrgA+ve/vacAs2+ve & 0 & $1(6 \%)$ & $1(8 \%)$ & $2(3 \%)$ \\
\hline cag T+ve/cagA-ve/cagE-ve/hrgA+ve/vacAs2+ve & 0 & 0 & $1(8 \%)$ & $1(1 \%)$ \\
\hline cagT+ve/cagA-ve/cagE+ve/hrgA+ve/vacAs1+ve & $3(7 \%)$ & $1(6 \%)$ & 0 & $4(6 \%)$ \\
\hline
\end{tabular}

bacterial factors; (b) proinflammatory host factors; (c) environmental factors. Besides host factors, such as cyclo-oxygenase (COX)-1, COX-2, inducible nitric oxide synthase (iNOS) and p53, and environmental factors, such as dietary habits, both of which are implicated in the pathogenesis of gastric cancer, recent studies have revealed an enhanced risk of gastric cancer in people infected with more virulent strains of $H$ pylori than those with less pathogenic $H$ pylori.

As it is well known that carcinogenesis is a multifactorial event and probably takes decades to manifest, it is important to begin to investigate the precise role played by this pathogen in the highly intricate process. As indicated by some studies, ${ }^{15}$ infection with $H$ pylori is not itself responsible for promoting the process of cancer; instead it acts as a trigger, initiating the carcinogenic pathway. This is usually accomplished by the major proteins (eg, CagA and VacA) secreted by H pylori, which, on injection into human host cells, undergo a complex series of modifications, thereby inducing the host cells to secrete inflammatory cytokines. These cytokines, in their attempt to eliminate $H$ pylori infection, continuously bombard the host tissue, causing mucosal damage either directly or indirectly. $H$ pylori strains are diverse, and some strains may have more malignant potential. Patients harbouring cagA/vacA-positive strains of $H$ pylori exhibit enhanced expression of various cytokines, thereby causing major DNA damage, which over time leads to accumulation of mutations, resulting in cancer. ${ }^{16}$ These patients have a higher grade of gastric inflammation and accelerated epithelial damage and thus have greater potential to develop gastric metaplasia than patients infected with cagA/ vacA-negative strains. ${ }^{16}$ These underlying facts indicate the need to screen and characterise $H$ pylori in individual disease conditions.

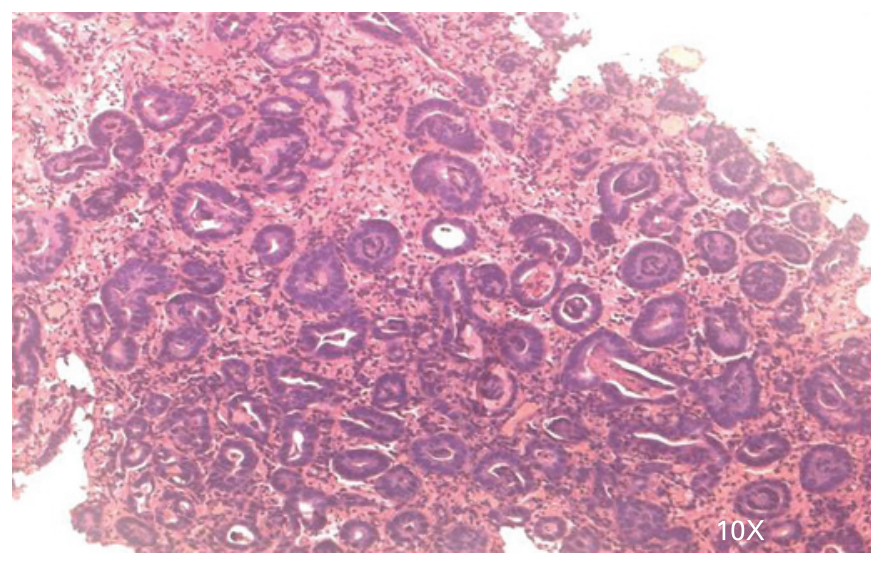

Figure 1 Invasion of stroma; dysplasia associated with invasive intestinal-type gastric adenocarcinoma.
Several criteria based on the different genes have been used to assess the virulence trait of this pathogen, the most acceptable hypothesis being one based on the presence of cag $\mathrm{A} .{ }^{17} \mathrm{~A}$ large number of studies have shown increased risk of gastric cancer in people with cagA+ve $H$ pylori. However, other data have revealed that the occurrence of gastric malignancy is independent of cagA status. ${ }^{18} \mathrm{~A}$ few studies have also implicated pivotal roles of other virulence factors ( $\operatorname{cag} \mathrm{E}, \operatorname{cag} \mathrm{T}$, vacA, babA and $h r g \mathrm{~A}$ ) in the aetiology of gastric cancer. ${ }^{19}$ Several genotypes of $H$ pylori have been reported to possess higher predictive value for the development of the severe form of the disease. ${ }^{2021}$ Genotype studies from India have reported on the common genotypes of $H$ pylori in patients with gastritis and peptic ulcer and a few cases of gastric carcinoma. ${ }^{22}$ Therefore the present study was designed mainly to characterise the strains of $H$ pylori found in patients with gastric carcinoma in and around Hyderabad, India.

\section{MATERIALS AND METHODS}

\section{Patients and classification of endoscopic findings}

Ninety-two patients (70 male, 22 female; age range 35-48 years, mean age 41.17 years) referred for routine endoscopy at the Department of Gastroenterology, Deccan College of Medical Sciences, Hyderabad, India and Department of Gastroenterology, Osmania General Hospital, Hyderabad, India during May-October 2007 were recruited into the study. Endoscopic findings were recorded and used to separate $H$ pyloripositive patients into three groups: group $1(\mathrm{n}=48)$, patients with gastric cancer; group $2(\mathrm{n}=20)$, patients with gastric ulcer; group $3(n=24)$, patients with non-ulcer dyspepsia. The institutional ethics committee approved the study protocol, and all the patients gave informed consent to participate in the

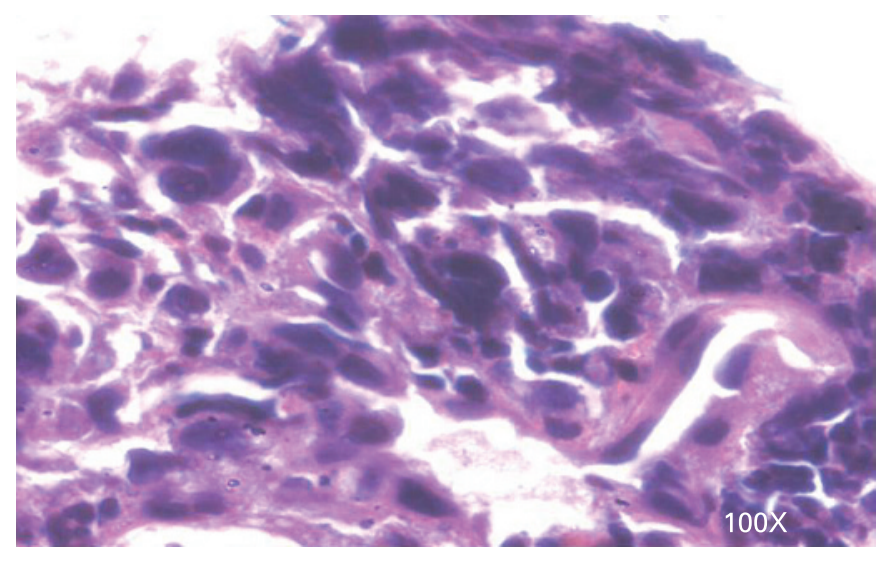

Figure 2 Gastric mucosal biopsy specimen showing presence of signet ring cell suggestive of diffuse-type carcinoma. 
study. Patients taking proton pump inhibitors and/or nonsteroidal anti-inflammatory drugs in the preceding month, with a history of gastrectomy, and/or had previous $H$ pylori eradication were excluded from the study.

\section{Methods}

During each endoscopic procedure, two antral and corpus mucosal biopsy specimens were obtained using biopsy forceps, which were cleaned with detergent and disinfected after each use. One of each specimen was placed in Brucella broth supplemented with $2 \%$ fetal calf serum and phosphate-buffered saline ( $\mathrm{pH} 7$ ) for culture and DNA isolation. If there was any growth in the stomach, an additional two specimens from the mass were collected in $10 \%$ buffered formalin for histopathological analysis of the nature of the growth.

\section{$H$ pylori cultivation and DNA isolation}

$H$ pylori was cultured routinely on Brucella agar (Becton Dickinson, Franklin Lakes, New Jersey, USA) with 7\% sheep blood and antibiotic supplement for 3 days at $37^{\circ} \mathrm{C}$ in a microaerophilic atmosphere $\left(5 \% \mathrm{O}_{2}, 10 \% \mathrm{CO}_{2}\right.$ and $\left.85 \% \mathrm{~N}_{2}\right)$. In subjects from whom live bacteria could not be cultured, genomic DNA was isolated the modified C-TAB method. ${ }^{20}$ Harvested culture and/or biopsy sample was suspended in $0.1 \mathrm{M} \mathrm{NaCl} / 10 \mathrm{mM}$ Tris/HCl/1 mM EDTA ( $\mathrm{pH}$ 8.0), sodium dodecyl sulphate $(1 \%, \mathrm{w} / \mathrm{v})$ was added, and the mixture was heated at $65^{\circ} \mathrm{C}$ and then extracted with phenol/chloroform/ isoamyl alcohol.

\section{Genotyping based on $\operatorname{cag} \mathrm{A}, \operatorname{cag} \mathrm{E}, \operatorname{cag} \mathrm{T}$, vacA and $h r g \mathrm{~A}$ genes of H pylori}

Isolated genomic DNA $(1 \mu \mathrm{l})$ was used to obtain the genotypes of $H$ pylori from individual patients using a multiplex PCR assay as previously reported. ${ }^{20}$ The list of oligonucleotide primers used in the study is reported. ${ }^{20}$

\section{Sequence analysis}

For sequencing, four samples from each group were randomly selected, and amplicons of each target gene were sequenced directly, after purification with the OIAquick gel extraction kit (Qiagen, Hilden, Germany) using the Big Dye Terminator V3.1 cycle sequencing kit and injected into an ABI 3730xl Genetic Analyzer (Applied Biosystems, Foster City, California, USA). Sequences were analysed and compared with data published in the NCBI database.

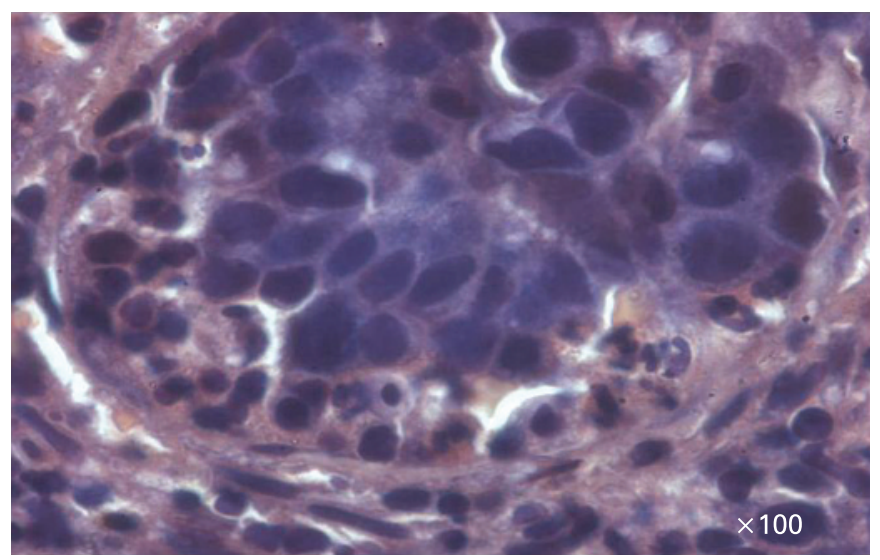

Figure 3 Infiltrative adenocarcinoma.

\section{Histopathological analysis}

Gastric biopsy specimens collected in 10\% buffered formalin were used to assess the nature (benign or malignant) of the lesions. Only cases with adequately sized specimens were accepted for histological assessment by an experienced pathologist (ZA), who was blinded to the clinical information on each patient.

The following histopathological variables were scored on an ordinal scale (0-3) using the criteria described in the updated Sydney classification system ${ }^{23}$ : $H$ pylori density, chronic inflammation, glandular atrophy, intestinal metaplasia and dysplasia. When present, intestinal metaplasia was typed as complete, mixed (complete and incomplete), or incomplete, and dysplastic changes were typed as low grade and high grade.

\section{Statistical analysis}

$\chi^{2}$ and Student $t$ tests were used as and where applicable for statistical calculation. $\mathrm{p}<0.05$ was considered significant.

\section{RESULTS}

$H$ pylori infection was diagnosed in 72 of the 92 subjects included in the study (gastric adenocarcinoma, 42; gastric ulcer, 18; non-ulcer dyspepsia, 12). H pylori infection was confirmed if any of the three tests - that is, culture, $16 \mathrm{~S}$ ribosomal RNA PCR and histopathology-were found to be positive.

\section{H pylori genotypes}

In the 72 subjects, PCR assay revealed genotype cagT+ve/ $\mathrm{hrgA}+\mathrm{ve} / \mathrm{cag} \mathrm{A}+\mathrm{ve} / \mathrm{cag} \mathrm{E}+\mathrm{ve} / \mathrm{vacAs} 1+\mathrm{ve}$ to be predominant (table 1). Overall, this genotype was found in $79 \%$ of all subjects included in the study.

\section{Genotypes of $\boldsymbol{H}$ pylori infection in the three clinical groups}

When the genotype data were correlated with individual disease status, cag T+ve/hrgA+ve/cagA+ve/cagE+ve/vacAs1+ve had a higher prevalence in group 1 (gastric adenocarcinoma; 37 $(88 \%))$ than in group 2 (gastric ulceration; 14 (78\%)) $(p<0.01)$. In group 3 (non-ulcer dyspepsia), six $(50 \%)$ patients harboured $H$ pylori with the above genotype; this prevalence is also significantly $(p<0.01)$ different from that in groups 1 and 2 .

\section{Histopathological correlation of genotypes}

Of the 48 patients with gastric carcinoma, 42 (88\%) showed $H$ pylori positivity. In the latter, histopathological examination showed mild intestinal metaplasia in 12 (29\%), moderate intestinal metaplasia in seven (17\%), low-grade dysplasia in eight (19\%), and high-grade dysplasia in 10 (24\%). Of the 42 subjects with $H$ pylori positivity, 35 (83\%) showed features of intestinal-type carcinoma (fig 1), three (7\%) showed patterns suggestive of diffuse carcinoma (fig 2$)$, two (5\%) had infiltrative

Table 2 Relationship between Helicobacter pylori genotype and type of gastric adenocarcinoma

\begin{tabular}{|c|c|c|c|c|}
\hline Genotype & $\begin{array}{l}\text { Intestinal } \\
(\mathrm{n}=35)\end{array}$ & $\begin{array}{l}\text { Diffuse } \\
(n=3)\end{array}$ & $\begin{array}{l}\text { Infiltrative } \\
(n=2)\end{array}$ & $\begin{array}{l}\text { Undifferentiated } \\
(\mathrm{n}=2)\end{array}$ \\
\hline $\begin{array}{l}\operatorname{cag} \mathrm{T}+\mathrm{ve} / h r g \mathrm{~A}+\mathrm{ve} / \operatorname{cag} \mathrm{A}+\mathrm{ve} / \\
\text { cag } \mathrm{E}+\mathrm{ve} / \mathrm{vacAs} 1+\mathrm{ve}\end{array}$ & 32 & 01 & 02 & 02 \\
\hline $\begin{array}{l}\operatorname{cag} \mathrm{T}+\mathrm{ve} / h r g \mathrm{~A}+\mathrm{ve} / \operatorname{cag} \mathrm{A}+\mathrm{ve} / \\
\operatorname{cag} \mathrm{E}+\mathrm{ve} / \mathrm{vacAs} 2+\mathrm{ve}\end{array}$ & 01 & 01 & 00 & 00 \\
\hline $\begin{array}{l}\operatorname{cag} \mathrm{T}+\mathrm{ve} / h r g \mathrm{~A}+\mathrm{ve} / \operatorname{cag} \mathrm{A}+\mathrm{ve} / \\
\operatorname{cag} \mathrm{E}-\mathrm{ve} / \mathrm{vacAs} 1+\mathrm{ve}\end{array}$ & 02 & 01 & 00 & 00 \\
\hline
\end{tabular}


adenocarcinoma (fig 3), and in two (5\%) the type of carcinoma could not be differentiated.

On analysis, a strong correlation was found between the presence of intestinal-type cancer and the genotype cagT+ve/ hrgA+ve/cagA+ve/cagE+ve/vacAs1+ve. Table 2 gives the details of the genotype and histological correlations.

\section{Sequence analysis}

Sequences obtained from PCR products of four randomly selected samples from each patient group were subsequently analysed using BLAST ${ }^{\mathrm{n}}$. The nucleotide sequences of the amplified products shared $98-100 \%$ homology with the cagA, cag T, cagE, hrgA and vacA genes of $H$ pylori.

\section{DISCUSSION}

This study shows a higher prevalence of $\operatorname{cagA} / \operatorname{cag} \mathrm{E} / \operatorname{cag} \mathrm{T} / \mathrm{hrg} \mathrm{A} /$ vacAs1-positive $H$ pylori in patients with gastric adenocarcinoma, especially the intestinal type, than those with other gastric disorders. These findings are consistent with previous reports by Koehler et al, ${ }^{21}$ Plummer et al ${ }^{24}$ and Soltermann et al, ${ }^{25}$ suggesting the pivotal role of $H$ pylori genotype in the clinical outcome of gastroduodenal diseases.

This study mainly emphasises the genotypic variants of $H$ pylori in patients with gastric adenocarcinoma, as only a few previous studies have been able to characterise $H$ pylori specifically in patients with gastric carcinoma. ${ }^{8}{ }^{26}$ Five virulent markers-cagA, cagE and cag T of the cytotoxin-associated gene pathogenicity island (cag-PAI), the signal peptide region of the vacuolating-associated cytotoxin (vacA), and $H$ pylori restriction endonuclease-replacing gene ( $\mathrm{rgA})$ of this pathogen-were selected on the basis of previous reports from different countries ${ }^{2127}$ and screened using specific oligonucleotide primers by a multiplex PCR assay developed by our group. ${ }^{20}$

Analysis of the 72 H pylori-positive subjects revealed cagT+ve/ hrgA+ve/cagA+ve/cagE+ve/vacAs1+ve to be the predominant genotype in $79 \%$ of them. Correlation of the genotype data with the clinical findings indicated that this genotype is highly prevalent in group 1 (88\%), followed by group 2 (78\%), with subjects with non-ulcer dyspepsia showing the lowest prevalence $(50 \%)$. These differences in prevalence are highly significant $(p<0.01)$. We also attempted to associate $H$ pylori genotype with the type of gastric carcinoma. Of the 42 subjects with endoscopically confirmed gastric cancer, histological analysis showed intestinal type in 35 (83\%), diffuse type in three $(7 \%)$, and infiltrative type in two (5\%). Male patients had an increased risk of developing intestinal-type carcinoma compared with female patients in our study population (data not shown). The reason for this may be the higher number

\section{Main findings of the study}

- Genotyping Helicobacter pylori in younger patients may be a useful strategy for identifying those with increased risk of gastric cancer.

- The genotype cagT+ve/hrgA+ve/cagA+ve/cagE+ve/ vacAs $1+v e$ had a higher predictive value for the overt form of gastric disease in our population.

- This retrospective study suggests that the combined presence of different virulent genes of $H$ pylori is the most effective for identifying patients at increased risk of developing gastric adenocarcinoma rather than screening only one or two genes. of male than female participants in the study. No correlation could be established between genotype and diffuse-type carcinoma because of the small sample size $(n=3)$ (table 2); however, the existence of such a relationship cannot be ruled out.

Sequencing analysis of the four samples randomly selected from each group did not show any strain-specific variation in relation to disease status. This signifies that $H$ pylori genotype has a definitive role in early-onset gastric cancer; the final outcome also depends on the age at acquisition, topographic distribution of $H$ pylori in the stomach, acid secretion, and associated pattern of gastritis. This finding agrees with those of Soltermann et al, ${ }^{25}$ who reported that virulence genotype of the microbe and age are important factors in the severity of gastritis and the development of intestinal metaplasia.

Although many previous reports have attempted to delineate the precise association between $H$ pylori genotype and gastric carcinoma, ${ }^{28-33}$ only a few ${ }^{28} 303133$ have been able to provide any information on the usefulness of any of the genes of this pathogen for predicting gastric carcinoma. The reason may be the genes selected. We used a combination of five different virulent markers for correlating genotype and clinical findings. We were not only able to correlate the genotype data with the clinical data, but we were also able to show the high risk of intestinal-type carcinoma in patients infected with the cagA/ cagE/cagT/hrgA/vacAs1 genotype.

Another important aspect of this study is that we included subjects in the age range 35-48 years; this differs from some previous studies ${ }^{27}$ in which the subjects were $>50$ years of age.

There are certain limitations of this study. The first is the small sample size. Secondly, although this study shows a high predictive value of cagA/cagE/cagT/hrgA/vacAs1-positive H pylori in patients with gastric cancer in our study population, it would be best for researchers worldwide to evaluate the prevalence of each individual gene, as the virulence of $H$ pylori varies from one population to another in different geographic areas. The reason may be the extreme genetic diversity of $H$ pylori at both the transcriptional and translational level, which in turn affects the function and antigenicity of the virulence factors associated with bacterial infection and ultimately the disease outcome. Over-interpretation of the data would therefore be avoided, and the genotypes of $H$ pylori that cause different diseases in different regions of the world would be determined. Thirdly, external factors such as dietary intake of antioxidants may also alter the clinical outcome of infection.

In conclusion, gastric cancer is a multistep, multifactorial disease, which involves the cumulative interplay of host, environmental and bacterial factors and probably takes several decades to manifest. Genotyping $H$ pylori infection may therefore be an ideal tool for identifying subjects at increased risk of developing gastric carcinoma, especially in young age groups. Finally, prospective studies evaluating expression profiles of the selected genes in different populations are needed to establish a link between $H$ pylori genotype and the entire spectrum of $H$ pylori-related gastroduodenal diseases including gastric carcinoma.

Acknowledgements: We thank T Neeraj for critical analysis during the course of the study, and other staff of the Osmania General Hospital for their help in the collection of biopsy samples.

Funding: This work was not supported by any grant from any source.

Competing interests: None.

Ethics approval: Ethics approval was obtained. 


\section{REFERENCES}

1. Ferlay J, Bray F, Pisani P, et al. GLOBOCAN 2000: cancer incidence, mortality and prevalence worldwide, version 1.0. IARC Cancer Base No 5. Lyon: IARC Press, 2001.

2. Crew KD, Neuget Al. Epidemiology of gastric cancer. World J Gastroenterol 2006;12:354-63.

3. Ries LAG, Kosary CL, Hankey BF, et al. International Agency for Research on Cancer Working Group on the Evaluation of Carcinogenic Risks to Humans. Schistosomes, liver flukes, and Helicobacter pylori. Lyon: International Agency for Research on Cancer, 1994:177-240.

4. Azuma T, Yamazaki S, Yamakawa A, et al. Association between diversity in the Src homology 2 domain containing tyrosine phosphatase binding site of Helicobacte pylori CagA protein and gastric atrophy and cancer. J Infect Dis 2004;189:820-7.

5. Ahmed KS, Khan AA, Ahmed I, et al. Impact of household hygiene and water source on the prevalence and transmission of Helicobacter pylori: a South Indian perspective. Singapore Med J 2007; 48:543-9.

6. Carvalho R, Milne ANA, van Rees BP, et al. Early onset gastric carcinomas display distinct molecular characteristics within gastric carcinogenesis. J Pathol 2004;204:75-83

7. Konturek SJ, Starzynska T, Marlicz K. Helicobacter pylori (HP), CagA status and plasma gastrin in the development of gastric cancer. Gut 2000;47(Suppl 1):A75.

8. Khanna AK, Seth P, Nath G, et al. Correlation of H. pylori and gastric carcinoma. J Postgrad Med 2002:48:27-8.

9. Eslick GD, Lim LL, Byles JE, et al. Association of $\mathrm{H}$. pylori infection with gastric carcinoma: a meta-analysis. Am J Gastroenterol 1999;94:2373-9.

10. Parsonnet J, Friedman GD, Vandersteen DP, et al. Helicobacter pylori infection and the risk of gastric carcinoma. N Engl J Med 1991;325:1127-31.

11. Forman D, Newell DG, Fullerton F, et al. Association between infection with Helicobacter pylori and risk of gastric cancer: evidence from a prospective investigation. BMJ 1991;302:1302-5.

12. Uemura N, Okamoto $\mathrm{S}$, Yamamoto $\mathrm{S}$, et al. Helicobacter pylori infection and the development of gastric cancer. N Engl J Med 2001;345:784-9.

13. Crowe SE. Helicobacter infection, chronic inflammation, and the development of malignancy. Curr Opin Gastroenterol 2005;21:32-8.

14. Hertog MG, Bueno-de-Mesquita HB, Fehily AM, et al. Fruit and vegetable consumption and cancer mortality in the Caerphilly Study. Cancer Epidemiol Biomarkers Prev 1996;5:673-7.

15. Mueller A, Falkow S, Amieva MR. Helicobacter pylori and gastric cancer: what can be learned by studying the response of gastric epithelial cells to the infection? Cancer Epidemiol Biomarkers Prev 2005;14:1859-67.

16. Zarrilli R, Ricci V, Roman M. Molecular response of gastric epithelial cells to Helicobacter pylori-induced cell damage. Cell Microbiol 1999;1:93-9.

17. Shimoyama T, Fukuda S, Tanaka M, et al. CagA seropositivity associated with development of gastric cancer in a Japanese population. J Clin Pathol 1998;51:225-8.
18. Held M, Engstrand L, Hansson LE, et al. Is the association between $H$. pylori and gastric cancer confined to CagA-positive strains? Helicobacter 2004;9:271-7.

19. Fischbach W, On-On Chan A, Chun-Yu Wong B. Helicobacter pylori and gastric malignancy. Helicobacter 2005;10:34-9.

20. Tiwari SK, Khan AA, Manoj G, et al. A simple multiplex PCR assay for diagnosing virulent Helicobacter pylori infection in human gastric biopsy specimens from subjects with gastric carcinoma and other gastro-duodenal diseases. J Appl Microbiol 2007; 103:2353-60.

21. Koehler $\mathbf{C l}$, Mues MB, Dienes HP, et al. Helicobacter pylori genotyping in gastric adenocarcinoma and MALT lymphoma by multiplex PCR analyses of paraffin wax embedded tissues. Mol Pathol 2003;56:36-42.

22. Ali M, Khan AA, Tiwari SK, et al. Association between cag-pathogenicity island in Helicobacter pylori isolates from peptic ulcer, gastric carcinoma, and non ulcer dyspepsia subjects with histological changes. World J Gastroenterol 2005;11:6815-22.

23. Dixon MF, Genta RM, Yardley JH, et al. Classification and grading of gastritis. The updated Sydney system. Am J Surg Pathol 1996;20:1161-81.

24. Plummer M, van Doorn L-J, Franceschi S, et al. Helicobacter pylori cytotoxinassociated genotype and gastric precancerous lesions. J Natl Cancer Inst 2007:99:1328-34

25. Soltermann A, Koetzer S, Eigenmann F, et al. Correlation of Helicobacter pylori virulence genotypes vacA and cagA with histological parameters of gastritis and patient's age. Mod Pathol 2007;20:878-83.

26. Sinha R, Anderson DE, McDonald SS, et al. Cancer risk and diet in India. J Postgrad Med 2003;49:222-8.

27. Nogueira C, Figueiredo C, Carneiro F, et al. Helicobacter pylori genotypes may determine gastric pathology. Am J Pathol 2001;158:647-54.

28. Ando T, Wassenaar M, Peek RM, et al. A Helicobacter pylori restriction endonuclease-replacing gene, $\mathrm{hrgA}$, is associated with gastric cancer in Asian strains. Cancer Res 2002;62:2385-9.

29. Ladeira MS, Rodrigues MA, Salvadori V, et al. Relationships between $\operatorname{cagA}$, vacA and iceA genotypes of Helicobacter pylori and DNA damage in the gastric mucosa. Environ Mol Mutagen 2004;44:91-8.

30. Maeda S, Ogura K, Yoshida $\mathrm{H}$, et al. Major virulence factors, vacA and cagA, are commonly positive in Helicobacter pylori isolates in Japan. Gut 1998;42:338-43.

31. Ogura K, Maeda S, Nakao M, et al. Virulence factors of Helicobacter pylori responsible for gastric diseases in Mongolian gerbil. J Exp Med 2000;192:1601-10.

32. Yamaoka Y, Kodama T, Gutierrez O, et al. Relationship between Helicobacter pylor iceA, cagA, and vacA status and clinical outcome: studies in four different countries. J Clin Microbiol 1999;37:2274-9.

33. Censini S, Lange C, Xiang Z, et al. cag, a pathogenicity island of Helicobacter pylori, encodes type I-specific and disease-associated virulencefactors. Proc Natl Acad Sci USA 1996;93:14648-53. 